\title{
Efficacy of Propolis Supplementation to Accelerate Healing Process and Body Weight Recovery of Pulmonary Tuberculosis Patients
}

\author{
Mahani $^{1,2}$, Ahmad Sulaeman ${ }^{1 *}$, Faisal Anwar ${ }^{1}$, Muhammad Rizal Martua Damanik', \\ Hardinsyah $^{1}$, Angelika Ploeger ${ }^{3}$ \\ ${ }^{1}$ Department of Community Nutrition, Faculty of Human Ecology, Bogor Agricultural University, \\ Bogor 16680, Indonesia \\ ${ }^{2}$ Department of Food Technology, Faculty of Agricultural Industrial Technology, Padjadjaran University, \\ Jatinangor 45363, Indonesia \\ ${ }^{3}$ Department of Organic Food Quality and Food Culture, Faculty of Organic Agricultural Sciences, \\ University of Kassel, D-37213, Germany
}

\begin{abstract}
This study aimed to evaluate the pace of curing process and body weight recovery of pulmonary tuberculosis $(\mathrm{Tb})$ patients receiving propolis supplementation. This study was a randomized controlled trial conducted on 50 pulmonary $\mathrm{Tb}$ patients that were assigned into three groups as follows: receiving standard-dose antituberculosis drugs (ATDs) +20 drops of placebo propolis (P0); receiving standarddose ATDs +20 drops of propolis with concentration of $6 \%$ (P1); and receiving standard-dose ATDs + 20 drops of propolis with concentration of $30 \%$ (P2). The results showed that the mean time ratio needed for sputum smear conversion to negative present of acid resitant bacteria in P0, P1 and P2 groups were weeks 10, 8 and 5, respectively. In the second week, mean body weight of P0 and P1 groups decreased by $2.4 \%$ and $0.2 \%$, respectively. In contrast, the mean body weight in P2 group increased by $1.5 \%$ $(\mathrm{p}<0.05$; Mann-Whitney test). In the same week, mean body mass index (BMI) of P0 and P1 groups decreased by 1.6 and 0.1 , respectively. Conversely, the mean BMI of P2 group increased by 0.3 . The changes were significantly different $(\mathrm{p}<0.05)$. The results conclusively indicated that supplementation of 20 drops of propolis with a concentration of $30 \%$ as an adjuvant to standard ATDs for the treatment of pulmonary $\mathrm{Tb}$ patients was beneficial to accelerate treatment effect and body weight recovery.
\end{abstract}

Keywords: body weight, cure, liquid propolis, pulmonary $\mathrm{Tb}$

\section{INTRODUCTION}

Tuberculosis $(\mathrm{Tb})$ is a global infectious disease problem and becoming the second leading cause of death after HIV/AIDS infection. Indonesia is ranked $2^{\text {nd }}$ out of 30 high burden countries in the world (WHO 2016). Tb treatment and cure requires regular consumption of anti-tuberculosis drugs (ATDs) every day without interruption for a substantially long term period. One of the problems faced in the use of ATDs to date is its hepatotoxic properties (Chowdhury et al. 2006; WHO 2013). The hepatotoxic effects of ATDs can cause decrease in appetite, nausea, dizziness, insomnia, fever and weight loss (Kemenkes 2009; Sudarsanam \& Tharyan 2014; Sari et al. 2014). These hepatotoxic effects further cause decline in nutritional status of the patients, whereas good nutritional status strongly supports cure (Semba \& Bloem 2001). Thus, the provision of hepatoprotective materials is expected to re- duce hepatotoxic effects that eventually may restore body weight (BW) faster.

Other studies conducted by Bhadauria et al. (2007), Hashmi et al. (2013) and Cevik et al. (2012) showed that propolis has a hepatoprotective properties, characterized by its ability to decrease SGPT and SGOT approaching the normal values and protection from liver damage in mice models. Pranandaru et al. (2011) found that propolis had the ability to fight $\mathrm{Tb}$ infection characterized by the sputum conversion--where acid-resistant bacteria (ARB) in the acid stained sputum smear is found negative--in Tb patients. Wahyunitisari et al. (2006) stated that altough propolis's ability to fight $\mathrm{Tb}$ infection was limited, it has several advantages when supplemented for $\mathrm{Tb}$ treatment such as it does not stimulate Mycobacterium tuberculosis to develop resistance and is more compatible with normal intestinal flora of $\mathrm{Tb}$ patients. Therefore, propolis has a potential to help overcome Tb problem in Indonesia. A num-

"Corresponding Author: asulaema06@gmail.com 
ber of studies have also revealed that propolis synergizes with ampicillin, gentamycin and streptomycin to eradicate M. tuberculosis (Scazzocchio et al. 2006); synergizes with streptomycin, rifampicin, isoniazid and ethambutol (Scheller et al. 1999); as well as synergizes with streptomycin and cloxacyllin (Krol et al. 1993). The synergy of propolis with antibiotics commonly use for $\mathrm{Tb}$ treatment, lead to potential acceleration of the healing process. However, a study from Halim et al. (2012) suggested that Indonesian propolis had a potential good efficacy, thus needs further study.

Based on the above reasoning, propolis with its dual ability (as hepatoprotector and also fighting $M$. tuberculosis infection) has a potential properties to accelerate the cure process and BW recovery of pulmonary $\mathrm{Tb}$ patients. Thus, this study aimed to evaluate the ability of propolis to accelerate the cure process and BW recovery of pulmonary $\mathrm{Tb}$ patients.

\section{METHODS}

\section{Design, location, and time}

The design used was randomized controlled trial, consisting of one positive control group and two treatment groups. The study was conducted in 24 public health centers (Puskesmas) in Bogor City, which lasted from December 1, 2015 to November 29, 2016. ATDs' packages were obtained from Puskesmas. Liquid propolis used was derived from the extraction of Geniotrigona incisa bee propolis from South Sulawesi that had passed a series of screening process.

\section{Sampling}

A total of $50 \mathrm{~Tb}$ patients were determined according to sample size table for controlled clinical trial with $\alpha$ of 0.05 and $80 \%$ power, resulting in 13 subjects per group (Chow et al. 2008). The subjects were recruited from all Puskesmas in Bogor City with a) inclusion criteria: Tb patients, adults aged 15-60 years, were willing to participate in the study by signing informed con- sent; and b) exclusion criteria: recurrent Tb patients, smoking, had hepatitis or other diseases that interfered the study, alcohol drinkers, pregnant, breastfeeding, using contraception, taking other drugs/herbal medicine/supplements. The subjects' age criterion was based on National Guidelines for Tuberculosis Control (Kemenkes 2014); i.e. adult patients (15 years or older). However, it was stated in the guidelines that adult patients aged over 60 years old were not able to tolerate drug dose of $>500 \mathrm{mg} /$ day, thereby the subjects in this study were adult patients aged 15-60 years. Considering that the age range was too wide and it had the potential to produce different responses to the intervention, the adult patients in this study were divided into two groups based on the age groupings by Ministry of Health (Kemenkes) (2009), namely adolescents (15-25 years) and adults (26-60 years).

The research consisted of one positive control group and two treatment groups (Table 1). Each subject received 6-month intervention according to National Guidelines for Tuberculosis Control (Kemenkes 2014). Permuted block randomization was used to obtain subjects with equal sex and age groups (Chow \& Liu 2004). Intervention and analysis were double-blinded (not known by the subjects, researchers, assistant or analyst).

Each group (P0, P1 and P2) had an equal number of subjects, either based on sex (male and female) or age groups (adolescents aged 1525 years and adults aged 26-60 years), by using permuted block randomization. The blocks in each group were made based on sex (male and female) and age groups (adolescents and adults). Thus, each group consisted of four blocks; i.e. 1) male-adolescents, 2) male-adults, 3) femaleadolescents and 4) female-adults. Each time a subject was obtained, the placement in the group was done by taking a roll of paper containing P0, $\mathrm{P} 1$ and P2 codes. The subjects were placed according the group code drawn. Placement of the subjects was repeated if there was a sequential placement more than once in the group and the block.

Table 1. Description of control and treatment provision on the subjects

\begin{tabular}{ccc}
\hline Group & $\begin{array}{c}\text { Intensive phase every day for } 8 \text { weeks } \\
\text { RHZE }(150 / 75 / 400 / 275)+\text { Propolis }\end{array}$ & $\begin{array}{c}\text { Continuation phase } 3 \text { times a week for } 16 \text { weeks } \\
\text { RH }(150 / 150)+\text { Propolis }\end{array}$ \\
\hline P0 & 4 4FDC tablets + 20 drops of placebo propolis & 4 2FDC tablets + 20 drops of placebo propolis \\
P1 & 4 4FDC tablets + 20 drops of $6 \%$ propolis & 4 2FDC tablets + 20 drops of $6 \%$ propolis \\
P2 & 4 4FDC tablets + 20 drops of 30\% propolis & 4 2FDC tablets + 20 drops of $30 \%$ propolis \\
\hline
\end{tabular}

Description: FDC = Fixed-Dose Combination. The dose of ATDs used was the dosage for adult patients according to the National Guidelines for Tuberculosis Control (Kemenkes 2014). 
Recruitment and screening of prospective subjects were performed by $\mathrm{Tb}$ program officers in all Puskesmas in Bogor City. The screening was conducted by listing, checking the sputum and interviewing the visitors in $\mathrm{Tb}$ eradication program section in Puskesmas. If the visitors met the inclusion and exclusion criteria, they were determined as prospective subjects. Prospective subjects were then offered to be research subjects. If they agreed, the Tb program officers in Puskesmas reported it to the researchers. Subsequently, the signing of informed consent was done by the researchers and the subjects, and continued with baseline data collection immediately before the intervention was conducted.

Distribution of ATDs to the subjects was conducted by Puskesmas's Tb program officers. Meanwhile, propolis distribution was done by the research assistant who also acted as a drug consumption supervisor (DCS). During the intensive treatment period (the first two months), the DCS visited the subjects every day to ensure that they actually consumed the ATDs and propolis. During the continuation treatment period (the $3^{\text {rd }}-6^{\text {th }}$ months), the DCS visited three times a week.

This study had obtained ethical approval from Health Research Ethics Committee, Faculty of Medicine of University of Indonesia number: 1036/UN2.F1/ETIK/2015.

\section{Data collection}

The observation parameters covered: 1) $M$. tuberculosis acid-resistant bacteria (ARB) that included positive 3 , positive 2 , positive 1 and negative in ARB; 2) anthropometric measurements: body height (measured once at the beginning), BW and body mass index (BMI). The data were collected in week 0 (before intervention as baseline data), every week during intensive treatment phase in the first two months, and every month during continuation treatment phase (from the $3^{\text {rd }}$ month to the $6^{\text {th }}$ month).

The materials used for sputum's ARB analysis (Ziehl-Neelsen stain method) were sputum of the subjects, $70 \%$ alcohol, carbol fuchsin, $3 \%$ alcohol, water, $0.3 \%$ methylene blue solution, $0.1 \%$ methylene blue solution and oil immersion. Meanwhile, the tools used were microscope slide, spirit lamp, sterile inoculating loop, staining rack and microscope. The tools used for anthropometric measurements were questionnaires, weight scales and height measurement tools.

Data on sputum's ARB status were obained at Puskesmas where subjects were asked to bring their collected morning sputum, the sputum at the time the patients were in Puskesmas was also collected for analysis. Bacteriological collection and analysis of ARB were conducted by Puskesmas officers. Body height data were obtained by measuring height of the $\mathrm{Tb}$ subjects at the beginning of the study using SH-2A height measurement tool, and it was performed by the Puskesmas officers. BW data were obtained by weighing the subjects using Camry EB9005 stepon scale in their respective homes, which was performed by the research assistant. BMI data were obtained by dividing the BW $(\mathrm{kg})$ with the square of height $\left(\mathrm{m}^{2}\right)$.

\section{Data analysis}

Sputum's ARB status data was processed and presented descriptively. Kruskal-Wallis test was used to analyze mean values of BW and BMI, while Mann-Whitney advanced test with significance level of 0.05 and 0.1 was used to analyze the significance of the difference in mean BW and BMI between treatments.

\section{RESULTS AND DISCUSSION}

\section{Subjects' characteristics}

The important characteristics of subjects that affected the response were sex and age. Therefore, this study used permuted block randomization to ensure that each group received equal distribution of sex and age resulted in distribution of sex (male-female) between the groups; i.e. $50.00 \%: 50.00 \%$ in $\mathrm{P} 0$ group, $50.00 \%: 50.00 \%$ in P1 group and 53.33\%:46.67\% in $\mathrm{P} 2$ group. Meanwhile, in terms of age, the mean age obtained were 30 years in P0 group, 30.1 years in P1 group and 29.3 years in P2 group. Thus, sex and age characteristics between groups were relatively equal, thereby the response that emerged was the result of the provison of intervention. Detailed subjects' characteristics are presented in Table 2.

\section{Acid resistant bacteria (ARB) conversion}

The bacteriological evidence treatment success of "cured" of Tb subjects was characterized by the occurrence of sputum smear conversion, from sputum smear positive in ARB into negative in ARB. The results of baseline sputum's ARB status analysis (before the intervention) are presented in Figure 1. Based on the figure, sputum's ARB status composition of $\mathrm{P} 0$ and P1 groups were relatively equal. Meanwhile, P2 group was tend to be more severe, dominated by nine $\mathrm{Tb}$ subjects $(60 \%)$ with positive 3 in sputum's ARB status. 
Table 2. Subjects' characteristics of the randomization results

\begin{tabular}{|c|c|c|c|}
\hline \multirow{3}{*}{ Variable } & \multicolumn{3}{|c|}{ Group } \\
\hline & P0 & $\mathrm{P} 1$ & P2 \\
\hline & $\mathrm{n}(\%)$ & $\mathrm{n}(\%)$ & $\mathrm{n}(\%)$ \\
\hline Initial number (N0) & 17 & 17 & 16 \\
\hline Drop out & $3(17.64)$ & $3(17.64)$ & $1(6.25)$ \\
\hline The final number (NA) & $14(82.36)$ & $14(82.36)$ & $15(93.75)$ \\
\hline \multicolumn{4}{|l|}{$\operatorname{Sex}(\mathrm{NA})$} \\
\hline Male & $7(50.00)$ & $7(50.00)$ & $8(53.33)$ \\
\hline Female & $7(50.00)$ & $7(50.00)$ & $7(46.67)$ \\
\hline Age range (NA);(years) & $15-47$ & $17-55$ & $17-54$ \\
\hline Mean age (NA);(years) & 30 & 30.1 & 29.3 \\
\hline \multicolumn{4}{|l|}{ Education (NA) } \\
\hline Did not have an education & $2(14.29)$ & $0(0.00)$ & $0(0.00)$ \\
\hline Dropped out of elementary school & $1(7.14)$ & $3(21.43)$ & $1(6.67)$ \\
\hline Graduated from elementary school & $2(14.28)$ & $3(21.43)$ & $4(26.67)$ \\
\hline Graduated from junior high school & $4(28.57)$ & $3(21.43)$ & $7(46.67)$ \\
\hline Graduated from senior high school & $5(35.71)$ & $5(35.71)$ & $3(20.00)$ \\
\hline \multicolumn{4}{|l|}{ Occupation (NA) } \\
\hline Civil servant & $0(0.00)$ & $0(0.00)$ & $1(6.67)$ \\
\hline Private employee & $3(21.43)$ & $2(14.28)$ & $1(6.67)$ \\
\hline Entrepreneur & $1(7.14)$ & $1(7.14)$ & $0(0.00)$ \\
\hline Others* & $10(71.43)$ & $11(78.57)$ & $13(86.67)$ \\
\hline \multicolumn{4}{|l|}{ Income (IDR); (NA) } \\
\hline Do not have income & $2(14.29)$ & $0(0.00)$ & $0(0.00)$ \\
\hline Less than $1,500,000 /$ month & $9(64.29)$ & $10(71.42)$ & $13(86.67)$ \\
\hline $1,500,000-<5,000,000 /$ month & $3(21.43)$ & $4(28.57)$ & $2(13.33)$ \\
\hline
\end{tabular}

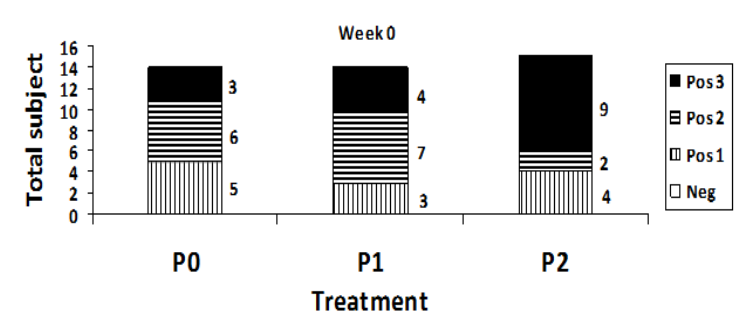

Figure 1. Bar chart of analysis results of the subjects' ARB in $\mathrm{P} 0, \mathrm{P} 1$, and $\mathrm{P} 2$ groups before intervention

The rate of sputum's ARB conversion process in each group was different. In P0 group, the conversion of sputum's ARB started to occur in the $6^{\text {th }}$ week on one subject $(7.1 \%)$. The next conversion in sputum's ARB occurred at weeks $7,8,12$ and 24 with conversion accumulation of $28.6 \%, 64.3 \%, 92.9 \%$ and $100 \%$, respectively. Conversion in sputum's ARB in P1 began to occur in the $6^{\text {th }}$ week on one subject $(7.1 \%)$. The subsequent conversion in sputum's ARB occurred at weeks 7,8 and 12 with conversion accumulation of $35.7 \%, 78.6 \%$ and $100 \%$, respectively. In
P2 group, sputum's ARB conversion began to occur in the $3^{\text {rd }}$ week on four subjects $(26.7 \%)$. The next conversion happened at weeks 4, 5, 7 and 12 with conversion accumulation of $66.7 \%, 86.7 \%$, $93.3 \%$ and $100 \%$, respectively.

There were differences in conversion rate of sputum's ARB in the three groups; i.e. the sputum smear conversion in $\mathrm{P} 2$ group occurred earlier than the other groups. In the $3^{\text {rd }}$ and $7^{\text {th }}$ weeks, conversion of sputum's ARB in P2 group had reached $93.3 \%$. In the same week (the $7^{\text {th }}$ week), the sputum's ARB conversion in P0 and P1 groups only reached $28.6 \%$ and $35.7 \%$ conversion, respectively. Furthermore, when the data was compared to the composition of baseline sputum's ARB status, the P2 group was in fact more severe than other groups.

Based on mean conversion time the healing of $\mathrm{P} 2$ group was the fastest, which was five weeks faster than P0 group and three weeks faster than $\mathrm{P} 1$ group. Therefore, the order of healing process was $\mathrm{P} 2>\mathrm{P} 2>\mathrm{P} 0$. The differences in healing rates between groups are presented in Figure 2. 


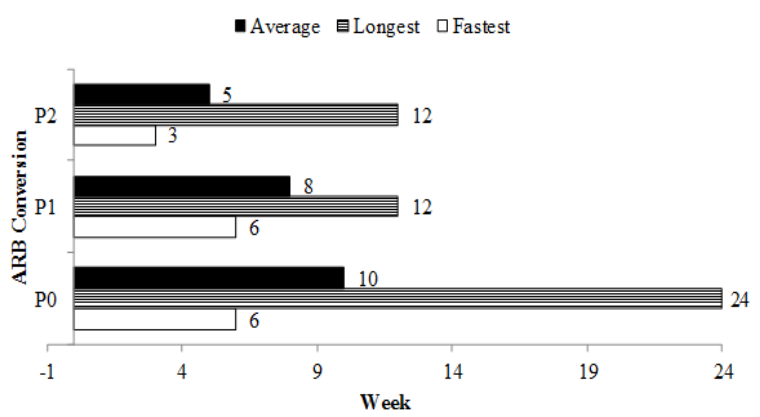

Figure 2. Bar chart of ARB conversion rates in$\mathrm{P} 0, \mathrm{P} 1$, and $\mathrm{P} 2$ groups

A faster recovery will give significant benefits to the subjects; i.e. nutrient intakes will be fully utilized to restore nutritional status, health and productivity maintenance, and can be used for growth for the subjects who are still in the growth period. Nutrient intakes of the subjects that had not cured were partially mobilized to fight infection. It was seen in the P2 group that directly experienced BW and BMI improvements since the first week. P1 group took three and four weeks to restore BW and BMI. P0 group took five weeks to restore BW and had not been able to restore the BMI until the end of the intervention.

Based on the above sputum smear bacteriological conversion data, propolis has shown good ability to fight $M$. tuberculosis infection. This result is in agreement with the study results of Syamsudin et al. (2008) and Pranandaru et al. (2011). The result also strengthens the study results of Scazzocchio et al. (2006), Scheller et al. (1999), and Krol et al. (1993) who have suggested that propolis synergizes with ATDs in fighting M. tuberculosis infection. The ability of propolis to fight $M$. tuberculosis is influenced by the active components in it, which is known to have anti- mycobacterial ability. Cantrell et al. (2001) have mentioned that compounds of diterpene, triterpene and sesquiterpene classes have anti-mycobacterial activity, even some of their derivatives show anti-tuberculin activity almost similar to ATDs. The compounds are found in propolis. Toreti et al. (2013) have reviewed the compounds contained in the propolis that act as antibacterial and antibiotic; i.e. flavanones, flavones, phenolic acids and esters, prenylated p-coumaric, labdane diterpenes, prenylated flavanones, and prenylated benzophenones. The study results of Katerere et al. (2012) have revealed that pinocembrin has anti-mycobacterial activity, and the activity of this compound is increased when coupled with other phytochemicals.

\section{Body weight (BW)}

Body weight is a standard measure of nutritional status and is sensitive to sudden changes such as infection and food consumption (Gershwin et al. 2004). The patterns of BW changes in P0 and P1 groups had similarities, whereas the pattern of BW change in P2 group was different. The percentages of mean $\mathrm{BW}$ changes are presented in Figure 3.

There was a decrease in BW of the subjects in P0 group until the $4^{\text {th }}$ week. Their weight began to recover (equal or higher than baseline $\mathrm{BW}$ ) in the $5^{\text {th }}$ week, with an increase of $0.8 \%$. Decreased BW was thought to be caused by hepatotoxic effects of ATDs (i.e. nausea, dizziness and decreased appetite), thus the food intake was lower than normal. The data on differences in food intakes between P0 group (ATDs + placebo propolis) and $\mathrm{P} 2$ group (ATDs $+30 \%$ propolis) in this study have been reported by Pranajaya (2017) as presented in Table 3. These data showed that nutritional adequacy level of P2 group was higher than $\mathrm{P} 0$ group.

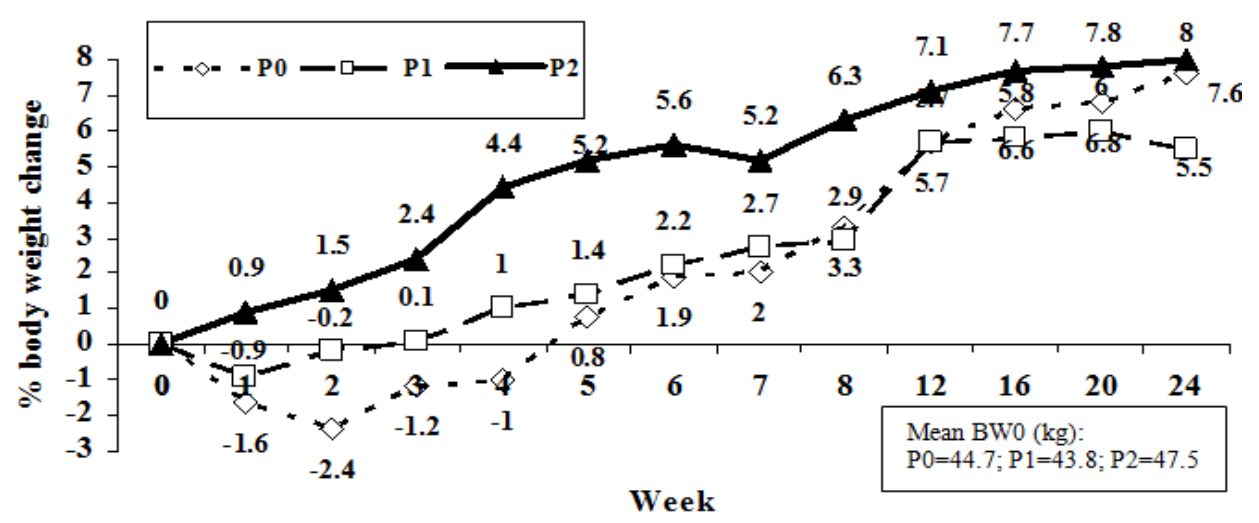

Figure 3. Percentage of mean body weight changes of the subjects in P0, P1 and P2 groups during intervention 
The subjects in the P1 group lost weight during the first two weeks. Their weight began to recover in the $3^{\text {rd }}$ week with an increase of $0.1 \%$. If compared with the changes in BW of $\mathrm{P} 0$ group, the BW of $\mathrm{P} 1$ group recovered two weeks earlier. It was allegedly due to the effect of hepatoprotective activity of propolis so that the hepatotoxic effects of ATDs decreased which leaded to appetite recovery, thereby the $\mathrm{BW}$ recovered faster.

In contrast to the other groups, the $\mathrm{P} 2$ group did not experience weight loss and immediately gained weight from the start of intervention. The BW continued to increase until the end of inter- vention. The increase in BW was proposed as the cause of propolis supplementation with a dose of $30 \%$ that effectively reduced the hepatotoxic effects of ATDs. The BW changes shown by all groups proved that $30 \%$ propolis supplementation was able to reduce the hepatotoxic effects of standard-dose ATDs. The differences in BW changes were particularly prominent, observed from the $2^{\text {nd }}$ week to the $6^{\text {th }}$ week of intervention. Statistically, BW changes in the $2^{\text {nd }}$ week were significantly different $(\mathrm{p}<0.05)$ (Table 4$)$.

Based on the observation on weight changes, there was a strong indication that intensive

Table 3. Mean nutritional adequacy level of the subjects (pulmonary Tb patients) receiving propolis supplementation and placebo before and after the intervention

\begin{tabular}{llccc}
\hline & & $\begin{array}{c}\text { Before } \\
\text { intervention }\end{array}$ & $\begin{array}{c}\text { After } \\
\text { intervention }\end{array}$ & Mean change \\
\hline \multirow{3}{*}{ Placebo group } & Energy & $56.6 \pm 17.7^{\mathrm{a}}$ & $62.3 \pm 13.7^{\mathrm{a}}$ & $5.7 \pm 13.6^{1}$ \\
& Protein & $34.4 \pm 15.6^{\mathrm{a}}$ & $40.9 \pm 16.1^{\mathrm{a}}$ & $6.5 \pm 14.9^{1}$ \\
& Fat & $48.8 \pm 23.6^{\mathrm{a}}$ & $57.9 \pm 22.7^{\mathrm{a}}$ & $9.1 \pm 27.8^{1}$ \\
& Carbohydrates & $66.0 \pm 24.4^{\mathrm{a}}$ & $66.5 \pm 14.3^{\mathrm{a}}$ & $0.6 \pm 21.8^{1}$ \\
& Energy & $52.3 \pm 21.8^{\mathrm{a}}$ & $65.1 \pm 16.1^{\mathrm{b}}$ & $12.8 \pm 20.7^{1}$ \\
& Protein & $31.1 \pm 15.6^{\mathrm{a}}$ & $48.8 \pm 12.0^{\mathrm{b}}$ & $17.8 \pm 13.2^{1}$ \\
& Fat & $48.7 \pm 27.7^{\mathrm{a}}$ & $61.6 \pm 28.1^{\mathrm{a}}$ & $12.9 \pm 29.4^{1}$ \\
& Carbohydrates & $59.1 \pm 25.3^{\mathrm{a}}$ & $68.1 \pm 17.9^{\mathrm{b}}$ & $9.0 \pm 27.2^{1}$ \\
\hline
\end{tabular}

Description: ${ }^{1}$ Different figures in the same column indicate significant differences between groups $(\mathrm{p}<0.05)$; ${ }^{\text {a different letters }}$ in the same row show significant differences between time $(\mathrm{p}<0.05)$.

Table 4. Kruskal-Wallis test and Mann-Whitney advanced test on the difference in mean BW of the subjects at weeks $1,2,6,8$ and 24

\begin{tabular}{lcccl}
\hline \multirow{2}{*}{ Response } & $\begin{array}{c}\text { Model test } \\
\text { (Kruskal-Wallis) }\end{array}$ & & \multicolumn{2}{c}{ Mann-Whitney advanced test } \\
\cline { 2 - 5 } & $\mathrm{p}$ & Treatment & $\mathrm{p}$ & \multicolumn{1}{c}{ Description } \\
\hline \multirow{2}{*}{$\begin{array}{l}\text { BWW1-BW0 } \\
\text { difference }\end{array}$} & $0.028^{*}$ & $\mathrm{P} 0-\mathrm{P} 1$ & 0.454 & Not significantly different \\
& & P0-P2 & 0.158 & Not significantly different \\
BWW2-BW0 & & P1-P2 & 0.029 & Significantly different at 5\% level \\
difference & $0.006^{*}$ & P0-P1 & 0.635 & Not significantly different \\
& & P0-P2 & 0.002 & Significantly different at 5\% level \\
BWW6-BW0 & & P1-P2 & 0.023 & Significantly different at 5\% level \\
difference & $0.000^{*}$ & P0-P1 & 0.062 & Significantly different at 10\% level \\
& & P0-P2 & 0.000 & Significantly different at 5\% level \\
BWW8-BW0 & & P1-P2 & 0.000 & Significantly different at 5\% level \\
difference & $0.000^{*}$ & P0-P1 & 0.104 & Not significantly different \\
& & P0-P2 & 0.000 & Significantly different at 5\% level \\
& & P1-P2 & 0.000 & Significantly different at 5\% level \\
BWW24-BW0 & 0.229 & P0-P1 & 0.804 & Not significantly different \\
& & P0-P2 & 0.186 & Not significantly different \\
& & P1-P2 & 0.134 & Not significantly different \\
\hline
\end{tabular}

*Significantly different at $5 \%$ level. 
use of ATDs caused a decrease in BW through the hepatotoxic mechanism. Hepatotoxic effects includes decreased in appetite, nausea and dizziness (Sari et al. 2014), thus the food intake decreased drastically that led to weight loss. The weight recovery was noticeable after entering continuation treatment period (the $9^{\text {th }}$ week until the $24^{\text {th }}$ week), either in the group not receiving propolis supplementation ( $\mathrm{P} 0$ ) or the groups receiving propolis supplementation (P1 and P2). It indicated that the subjects could recover from the toxic effects of ATDs. Statistically, the mean BW in all groups at the end of intervention were not significantly different.

Propolis supplementation in this study provided additional benefit of liver protection from the toxic effects of ATDs, especially in the first two weeks of intensive treatment phase. Liver protection by the propolis was ultimately useful to accelerate the BW recovery of the subjects. The results of this study strengthened the study results of Bhadauria et al. (2007), Hasmi et al. (2013) and Cevik et al. (2012) who stated that propolis was hepatoprotective. It was also seen that the higher the dosage of propolis supplementation, the faster and higher the BW recovery is. In this study, the BW recovery of the patients in P2, P1 and P0 groups occurred at weeks 1, 3, and 5 , respectively.

\section{Body mass index (BMI)}

BMI is one of the adult nutritional status indicators. Based on the changes in mean difference of BMI, P0 group experienced a decrease in BMI since the beginning of intervention and had not recovered until the end of intervention (24 weeks). The final BMI remained negative $(-0.2)$.
The decrease in BMI was very drastic during the $1^{\text {st }}$ and $2^{\text {nd }}$ weeks (W1 and W2) and it continued until the $8^{\text {th }}$ week (W8). In continuation treatment period (from the $9^{\text {th }}$ week to the end of intervention), BMI had increased slowly. These data indicated that intensive provision of ATDs could suppress the nutritional status of the subjects as a result of its hepatotoxic effects. The changes in mean BMI are presented in Figure 4.

In the continuation treatment phase (ATDs administered only 3 times a week), the strength of pressure on nutritional status was also reduced. In the P1 group, the decrease in BMI occurred during the first three weeks and started to be positive in the $4^{\text {th }}$ week $(0.1)$. In the $24^{\text {th }}$ week, BMI increased by 0.9 . When compared to P0 group, the decrease in nutritional status in P1 group was smaller, and it occurred in shorter duration. It means that supplementation of 20 drops of $6 \%$ propolis in ATDs provide benefits for nutritional status recovery of the subjects.

Unlike the other groups, the $\mathrm{P} 2$ group immediately experienced an increase in BMI from the beginning of intervention and it continued to increase until the end of intervention. In the first week, the BMI increased by 0.2 . BMI continued to increase until the $8^{\text {th }}$ week (W8) and the increase reached 1.2. Therefore, the BMI increased by 1.2 during the intensive treatment period. The final BMI (W24) reached 1.5. Thus, it could be said that the BMI increased only by 0.3 during the four months of continuation treatment period. These data showed that $\mathrm{P} 2$ group had a rapid increase in nutritional status in the intensive period. It showed a strong indication that daily supplementation using 20 drops of $30 \%$ propolis in ATDs could accelerate the nutritional status recovery of the subjects.

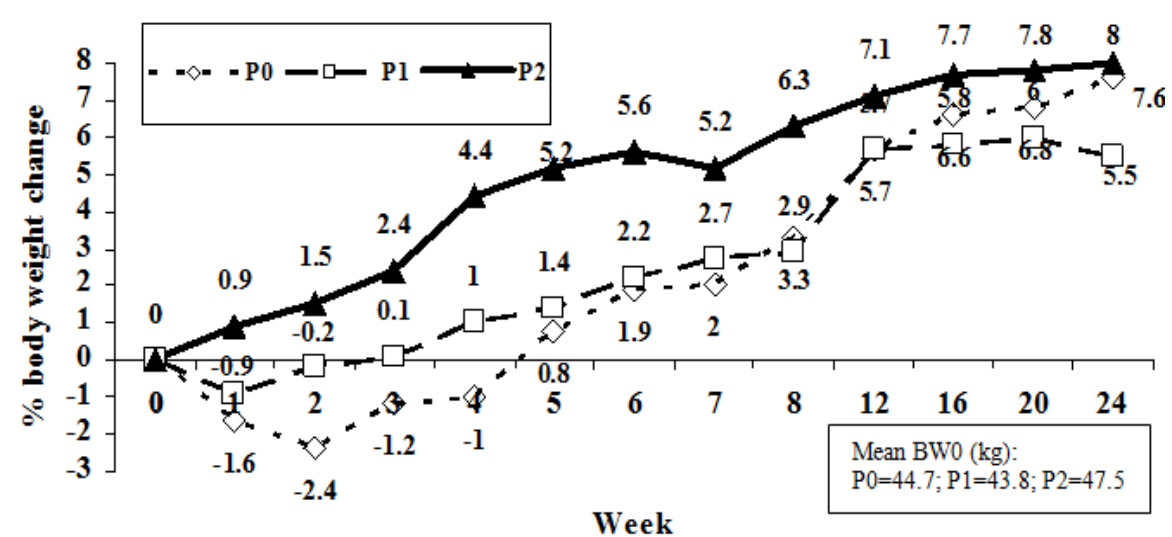

Figure 4. Changes in mean body mass index differences of the subjects in $\mathrm{P} 0, \mathrm{P} 1$ and $\mathrm{P} 2$ groups during intervention 
Table 5. Kruskal-Wallis test and Mann-Whitney advanced test on the difference in mean BMI of the subjects at weeks $1,2,6,8$ and at the $6^{\text {th }}$ month

\begin{tabular}{lcccl}
\hline \multirow{2}{*}{ Response } & $\begin{array}{c}\text { Model test } \\
\text { (Kruskal-Wallis) }\end{array}$ & & \multicolumn{2}{c}{ Mann-Whitney advanced test } \\
\cline { 2 - 5 } & $\mathrm{p}$ & Treatment & $\mathrm{p}$ & \multicolumn{1}{c}{ Description } \\
\hline BMIW1-BMI0 & $0.030^{*}$ & P0-P1 & 0.769 & Not significantly different \\
difference & & P0-P2 & 0.051 & Significantly different at 10\% level \\
& & P1-P2 & 0.063 & Significantly different at 10\% level \\
BMIW2-BMI0 & $0.001^{*}$ & P0-P1 & 0.125 & Not significantly different \\
difference & & P0-P2 & 0.000 & Significantly different at 5\% level \\
& & P1-P2 & 0.037 & Significantly different at 5\% level \\
BMIW6-BMI0 & $0.014^{*}$ & P0-P1 & 0.482 & Not significantly different \\
difference & & P0-P2 & 0.006 & Significantly different at 5\% level \\
& & P1-P2 & 0.029 & Significantly different at 5\% level \\
BMIW8-BMI0 & $0.054^{* *}$ & P0-P1 & 0.329 & Not significantly different \\
difference & & P0-P2 & 0.023 & Significantly different at 5\% level \\
& & P1-P2 & 0.123 & Not significantly different \\
BMIW24-BMI0 & 0.135 & P0-P1 & 0.541 & Not significantly different \\
difference & & P0-P2 & 0.063 & Significantly different at 10\% level \\
& & P1-P2 & 0.158 & Not significantly different \\
\hline
\end{tabular}

Description: *) Significantly different at 5\% level, **) Significantly different at 10\% level.

The statistical evidence of benefit from propolis supplementation to restore BMI was also reinforced by Kruskal-Wallis test and MannWhitney advanced test, which showed that the changes in $\mathrm{BMI}$ in $\mathrm{P} 2$ and $\mathrm{P} 0$ groups were significantly different from the first week until the $24^{\text {th }}$ week $(\mathrm{p}<0.05$ and $\mathrm{p}<0.1)$ (Table 5).

Observation on the pattern of BMI changes showed that the BMI recovery of P1 and P2 groups occurred at week 4 and week 1, respectively. Meanwhile, BMI of the P0 group had not recovered until the $24^{\text {th }}$ week. It was also seen that intensive use of ATDs might cause a decrease in nutritional status (as shown from the decreased in $\mathrm{BMI}$ of $\mathrm{P} 0$ and $\mathrm{P} 1$ groups within the intensive treatment period). Conversely, the supplementation of 20 drops of $30 \%$ propolis alongside the ATDs could reduce the effect of decreased nutritional status due to ATDs consumption. Moreover, it also could improve nutritional status of the subjects.

In line with the results of this study, Shetty (2010) stated that there was an interaction between undernutrition and infection. The BMI data above showed that $M$. tuberculosis infection might decrease the nutritional status of the subjects through certain mechanism. The results of this study were also in agreement with the re- search results of Moses et al. (2009); Tungdim and Kapoor (2008); Lombardo (2012); Patra et al. (2010), Sultan et al. (2012), and Chung-Delgado et al. (2014), who found that Tb patients significantly had lower nutritional status compared to the healthy population.

\section{CONCLUSION}

Based on the sputum smear ARB conversion, the propolis supplementation groups $(\mathrm{P} 1$ and P2) recovered faster than the placebo propolis supplementation group (P0). Higher concentration of propolis lead to faster sputum's conversion. Similarly with the changes in mean BW, in which higher concentration of propolis supplement result in faster BW recovery. Furthermore, $\mathrm{BW}$ of $\mathrm{P} 2$ group had increased immediately from the beginning. Thus, supplementation of 20 drops of propolis with a concentration of $30 \%$ along with ATDs during the treatment are effective to accelerate the cure and BW recovery processes of pulmonary $\mathrm{Tb}$ patients. Considering that propolis is clinically proven to be able to accelerate cure and $\mathrm{BW}$ recovery of pulmonary $\mathrm{Tb}$ patients, it has a potential to be used as a supplement for national $\mathrm{Tb}$ control. 


\section{ACKNOWLEDGEMENTS}

We would like to thank the Directorate General of Research and Development Reinforcement - Ministry of Research, Technology and Higher Education for the research funding through the International Research Collaboration and Scientific Publication scheme Number: 079/SP2H/LT/DRPM/II/2016 dated 17 February 2016. We also would like to express our gratitude to Health Office of Bogor City, especially dr. Eddy Darma, MKKK, dr. Siti Robiah Mubarokah and Mr. Budi Wibowo, Amd, Kep and all Puskemas's $\mathrm{Tb}$ program officers in Bogor City for the support of this research integration in Tb prevention in Bogor City.

\section{REFERENCES}

Bhadauria M, Nirala SK, Shukla S. 2007. Duration-dependent hepatoprotective effects of propolis extract against carbon tetrachloride-induced acute liver damage in rats. Adv Ther 24:1136-1145.

Cantrell CL, Franzblau SG, Fischer NH. 2001. Antimycobacterial plant terpenoids. Planta Med. 67:685-694.

Cevik MU, Acar A, Tanriverdi H, Varol S, Arikanoglu A, Yucel Y, Akil E, Yunce M, Ekinci A. 2012. Toxic Effects of Isoniazid and Rifampicin on Rat Brain Tissue: The Preventive Role of Caffeic Acid Phenethyl Ester. Int J Pharmacol 8:555-560.

Chow SC, Liu JP. 2004. Design and Analysis of Clinical Trials : Concepts and Methodologies. 2nd ed. John Wiley \& Sons, Inc. New Jersey : Hoboken.

Chowdhury A, Santra A, Bhattacharjee K, Ghatak S, Saha DR, Dhali GK. 2006. Mitochondrial oxidative stress and permeability transition in Isoniazid and Rifampicin induced liver injury in mice. J. Hepatol. 45, 117-126. doi:10.1016/j.jhep.2006.01.027

Chung-Delgado K, Revilla-Montag A, GuillénBravo S, Bernabe-Ortiz A. 2014. Weight variation over time and its relevance among multidrug-resistant tuberculosis patients. Int. J. Infect. Dis. 23, 20-24. doi:10.1016/j.ijid.2014.01.001

[Depkes] Departemen Kesehatan. 2009. Profil Kesehatan Indonesia 2008. Departemen Kesehatan Republik Indonesia, Jakarta.

Gershwin ME, Nestel P, Keen CL. 2004. Handbook of Nutrition and Immunity. Humana Press Inc. Totowa, New Jersey.
Halim E, Hardinsyah, Sutandyo N, Sulaeman A, Artika M, Harahap Y. 2012. Kajian Bioaktif dan Zat Gizi Propolis Indonesia dan Brasil. J Gizi Pangan 7(1):1-6.

Hashmi N, Muhammad F, Javed I, Khan JA, Khan MZ, Khaliq T, Aslam B. 2013. Nephroprotective effects of Ficus religiosa linn (peepal plant) stem bark against isoniazid and rifampicin induced nephrotoxicity in albino rabbits. Pak Vet J 33:330-334.

Katerere DR, Gray AI, Nash RJ, Waigh RD. 2012. Phytochemical and Antimicrobial Investigations of Stilbenoids and Flavonoids Isolated from Three Species of Combretaceae. Fitoterapia 83 (2012) 932-940

[Kemenkes] Kementerian Kesehatan Republik Indonesia. 2009. Keputusan Menteri Kesehatan Republik Indonesia Nomor 364/ Menkes/Sk/V/2009 Tentang Pedoman Penanggulangan Tuberkulosis (Tb).

[Kemenkes] Kementerian Kesehatan Republik Indonesia. 2014. Pedoman Nasional Pengendalian Tuberkulosis. Kementerian Kesehatan Republik Indonesia. Direktorat Jenderal Pengendalian Penyakit dan Penyehatan Lingkungan.

Krol W, Scheller S, Shani J, Pietsz G, Czuba Z. 1993. Synergistic Effect of Ethanolic Extract of Propolis and Antibiotics on The Growth of Staphylococcus aureus. Arzneimittelforschung. 43(5):607-9.

Lombardo CC. 2012. The nutritional status of patients with tuberculosis in comparison with tuberculosis-free contacts in Delft, Western Cape. South Afr J Clin Nutr 25: 180-185.

Moses AO, Emmanuel OO, Ganiyu AO, Fidelis AA, Dickson AO. 2009. Assessment of antioxidants and nutritional status of pulmonary tuberculosis patients in Nigeria. Eur $\mathrm{J}$ Gen Med 5(4):208-211

Patra SK, Jain A, Sherwal BL, Khanna A. 2010. Nutritional Status in Multi Drug Resistance-Pulmonary Tuberculosis Patients . Int. J. Pharma and Bio Sciences V 1(2).

Pranandaru HA, Sembodo J, Choirina, Wijaya FK, Sewaka SW. 2011. Propolis Sebagai Suplemen Bagi Penderita Tuberkulosis Dewasa. PKM Penelitian. Dikti Kemendikbud.

Sari ID, Yuniar Y, Syaripuddin M, 2014. Studi Monitoring Efek Samping Obat Antituberkulosis Fdc Kategori 1 di Provinsi Banten dan Provinsi Jawa Barat. Media Penelit. 
dan Pengemb Kesehat 24:28-35.

Scazzocchio F, D'Auria FD, Alessandrini D, Pantanella F. 2006. Multifactorial Aspects of Antimicrobial of Propolis. Microbiological Research 161(4):327-333.

Scheller S, Dworniczak S, Waldemar-Klimmek K, Rajca M, Tomczyk A, Shani J. 1999. Synergism between ethanolic extract of propolis (EEP) and anti-tuberculosis drugs on growth of mycobacteria. Naturforsch $\mathrm{C}$ 54(7-8):549-53.

Semba RD, Bloem MW. 2001. Nutrition and Health in Developing Countries. New Jersey: Humana Press.

Shetty P. 2010. Nutrition, Immunity and Infection. CABI Head Office Nosworthy Way 875.

Sudarsanam TD, Tharyan P. 2014. Rifampicin compared to isoniazid for preventing active $\mathrm{Tb}$ in HIV-negative people at risk of developing active $\mathrm{Tb}$ : Implications for public health. Clin. Epidemiol. Glob. Health 2, 28-36. doi:10.1016/j.cegh.2013.11.003

Sultan KM, Alobaidy MW, Al-Jubouri AM, Naser AA, Al-Sabah HA. 2012. Assessment of body mass index and nutritional status in pulmonary tuberculosis patients. J Fac Med Baghdad 54:204-208.

Syamsudin, Dewi RM, Kusmardi. 2008. Immu- nomodulatory and in vivo Antiplasmodial Activities of Propolis Extracts. Global Journal of Pharmacology 2(3):37-40.

Toreti VC, Sato HH, Pastore GM, Park YK. 2013. Recent Progress of Propolis for Its Biological and Chemical Compositions and Its Botanical Origin. Hindawi Publishing Corporation, Evidence-Based Complementary and Alternative Medicine. Volume 2013, Article ID 697390, 13 pages.

Tungdim MG, Kapoor S. 2008. Tuberculosis treatment and nutritional status among the tribals of Northeast India. Acta Biol. Szeged 52:323-327.

Wahyunitisari MR, Mertaniasih NM, Rachmawati D. 2006. Antimicrobial activities of andrographolide and propolis against intracellular Mycobacterium tuberculosis phagocytosed by monocytes derived macrophages. Folia Medica Indones 42:22-27.

[WHO] World Health Organization, 2016. Global Tuberculosis Report 2016. World Health Organization, Geneva, Switzerland.

[WHO] World Health Organization, 2013. Global Tuberculosis Report 2013. World Health Organization, Geneva, Switzerland. 